\title{
Prospects and limitations of agriculture industrialization in Nepal
}

\author{
Mina Nath Paudel \\ National Agriculture Genetic Resource Centre, Khumaltar \\ Email: mnpaudel@gmail.com
}

\begin{abstract}
Nepal is culturally an agriculture based country. One third of GDP comes from agriculture and there are numerous opportunities in agriculture mainly because of varied agro-climate prevailed in the country. Niche specific commodities that have comparative advantage could be produced in fair quantity to meet the demand of huge market of neighboring India and China as purchasing capacity of people in those countries has improved markedly mainly for quality agriculture commodities. Trade deficit, food insecurity, income generation, poverty reduction, and employment generation could be addressed by turning present status of subsistence agriculture into robust, vibrant and commercial agriculture through technology led agro-industrialization. There are agro-commodities which are imported from India and other countries in huge quantity by the scarce hard currency earned through remittance. Evidence shows that almost $70 \%$ of the remittance is spent for agriculture commodities which have high potentiality to produce within the country even after local consumption. Such produce could be exported to other countries to mitigate trade imbalance, enhance export promotion and import reduction and promote graduating Nepal from LDC to DC within the stipulated time frame as proposed a couple of years ago by the government of Nepal. Nepal should come up with functional, pragmatic and implementable agriculture plan and policy to harness huge possibility of agriculture commercialization to meet the consumption demand per se within and outside the country. This paper highlights to address prospects and limitations of agriculture commercialization and suggests some way forward to make agriculture more vibrant and robust to address trade deficit, food and nutritional insecurity and livelihood enhancement of Nepalese as a whole thereby Nepal can tailor her pace of development with neighboring countries to meet the aspiration of Nepalese in the $21^{\text {st }}$ century.
\end{abstract}

Key words: prospects and limitations, agriculture industrialization, way forward of agriculture

\section{Methodology}

This is a policy paper giving emphasis on prospects and limitations of Nepalese agriculture as a whole. Discussions on different issues have been given by a thorough review of literatures available within and outside the country. Aside from this, practical experience of author who was involved in agriculture R\&D of Nepal since four decades are also included in the pertinent issues encompassing agriculture systems in Nepal. Many of these 
issues have been presented and shared in different professional forum to help chalk out future course of action for agriculture industrialization in Nepal.

\section{Brief history and location of Nepal}

In the mid-18 ${ }^{\text {th }}$ century, Prithvi Narayan Shah, the founding father of modern Nepal, set out to put together all small kingdoms in which there were small territories ruled by small and scattered clans giving different names within modern Nepal popularly called " $22-24$ Rajyas" alias 22-24 kingdoms. Prithivi Narayan Shah founded Nepal in 1768 by unifying all those small kingdoms ruled by so called kings, in fact the clans. Hence, Prithivi Narayan Shah's monarchial dynasty ruled Nepal from 1768 - 2008. In June 1, 2001 King Birendra, the $10^{\text {th }}$ ruler of Shah Dynasty and his whole family including other royal family members were massacred in the Narayan Hiti Royal Palace, Kathmandu. Of his three brothers' only survived brother ruled Nepal up to 2008 when Nepal was declared republic. During this time of Shah Dynasty there were many political ups and downs in Nepal. Nepal is ever independent since its inception in 1768 and Nepalese are proud to be the citizens of one of the sovereign countries in the world. There were wars fought by world famous warriors "Brave Gurkkas" who kept Nepal ever independent. Consequently, Nepal promulgated her new constitution on September 20, 2015. Now in the federal republic system, there are elected president and parliamentary form of government in accordance to the constitution of Nepal 2015. Nepal with a total area of 147,181 square kilometers and population of 27.5 million (Population Census, 2011) is situated in Asia between India and China. Nepal's GDP based on PPP (purchasing power parity) was last recorded at 2265.42 US dollars in 2014 (http://www.tradingeconomics.com/nepal/gdp-percapita-ppp).

Before modern Nepal was founded by the Prithivi Narayan Sah, Neolithic tools found in the Kathmandu valley indicate that people have been living in the Himalayan region for at least eleven thousand years (Bhattarai, 2008). Nepal is first mentioned in the late Vedic Atharvaveda Parisista as a place exporting blankets and in the postVedic Atharvashirsha Upanishad (Baral, 1996). In Samudragupta's Allahabad Pillar it is mentioned as a bordering country. The Skanda Purana has a separate chapter known as "Nepal Mahatmya" that explains in more details about the beauty and power of Nepal (http://www.gktoday.in/current-article-indias-bilateral-relationships-nepal)/. Nepal is also mentioned in Hindu texts such as the Narayana Puja (Baral, 1996). It explains that existence of Nepal was known even in the Vedic and still older time of different periods. These ancient literatures justify that Nepal is one of the few oldest countries in the world. 


\section{Physiography and agro-climate}

Nepal is located in South Asia in coordinates of $28^{\circ} \mathrm{N}$ and $84^{\circ} \mathrm{E}$ and it is situated in between China in the north and India, in the east, west and south. Geographically Nepal is divided into five main regions; the Himalaya, high hills, mid-hills, Siwalik and, and Terai, however, agro-ecologically, Nepal is divided into (hills both high and mid), Siwalik and Terai. Nepal is primarily divided into five major physiographic regions which run in more or less parallel bands from northwest to southeast. Each of these regions has a distinctive agricultural and forestry land utilization pattern. These regions are known as the Himalaya, high mountains, middle mountains, Siwalik, and Terai. Nepal, noted for her majestic Himalayas, the roof of the world, Sagarmatha, Mount Everest $(8848 \mathrm{~m})$ in the north and the lowest point Kechanakal $(60 \mathrm{~m})$ in the south (Paudel, 2013). The Himalayas which in Sanskrit means the home of snow, the water towers, which supply water to the Indogangetic plain of Indian subcontinent, are the proud of the mountainous and hilly country, Nepal. Its shape is roughly rectangular, about 650 kilometers long and about 200 kilometers wide (Paudel and Sharma, 2009).

The climate of Nepal varies from subtropical to arctic, all within a distance of approximately 180 kilometers. In addition to the broad differentiations in climate, there is a great variety of micro climatic conditions, resulting in a diversity of land use and land practices within the country. In general, the climate of the Terai, Dun valleys, and part of the Siwaliks (300-1000m) is subtropical. The climate of the middle mountains (1000$3000 \mathrm{~m}$ ) ranges from warm temperate to cool temperate, and the high mountains (2600$4200 \mathrm{~m}$ ) from cool temperate to sub-alpine. The climate of mountain region is pleasant and amicable for many flora and fauna. Above mountain region there is Himalaya $(>4200 \mathrm{~m})$ and which is represented by tundra and high alpine climate. The monsoon, which lasts from June to September, is the most outstanding feature of the climate in Nepal. Nepal is called the micro-museum of world climate mainly because there are climatic zones ranging from tropical to tundra with a narrow band of altitude representing almost all available climates of the world.

There is mono-model peak of monsoon which commences from second week of June and recess in fourth week of September. This is the prime season for main rice growing period which is accompanied by a northwesterly airflow from the Bay of Bengal. Hence, its onset is first experienced in the east of the country while the period from October to March is mainly dry. Annual rainfall varies from 1400-1800 mm having more in the east and scanty in the west where as temperature varies from Terai to the Himalayan region. There is temperate alpine climate in the high mountain, pleasant and Mediterranean types in the mid hills and subtropics in the Terai having extreme temperature up to $40^{\circ} \mathrm{C}$ in summer and cold and hazy winter. There is occasional precipitation in the form of winter rains, caused by an eastward airflow from the Mediterranean, with local surface heating and/or 
orographic effects. The influence of these winter rains tends to be stronger in the west than in the east. The rains are of great importance for winter crops such as wheat and barley winter legumes and vegetables. In the east of the country the pre-monsoon rains generally last longer, facilitating two monsoon crops in many areas. The impact of global warming has been experienced in the Himalaya regions that had resulted permafrost thinning and formation of glacial lakes in the Himalaya regions (Paudel and Sharma, 2009).

\section{Agriculture systems}

Agriculture in Nepal is the main stay of people. Population engaged in agriculture is $65.6 \%$ with the cultivated agriculture land of 30, 91,000 ha and share of agriculture gross domestic product (AGDP) at current price of 2013/14 is 32.61\% (MoAD 2013/14). Growth rate of agriculture sector during this period was $4.7 \%$ while for non-agriculture sector it was $5.3 \%$ and these sectors had grown by 1.1 and 4.6 percent, respectively in the previous year (Nepal Rastra Bank, 2013/14). On the other hand, per annum population growth rate in the last year was $1.35 \%$, a growth rate higher than agriculture growth rate by $0.25 \%$. It clearly shows that agriculture growth is trailing behind population growth in the country. Therefore, agriculture should get high priority to feed the burgeoning population of 26.5 millions in Nepal (Population census, 2011).

\section{Limitation of agriculture}

Nepal is small country with considerable agro-climatic variation. In a broad geographic sense it is divided into the Himalaya, hills and mountain and Terai. The Himalayas are covered with snow round the year in $15 \%$ of the total areas of the country. Mid hills and mountain covers about $68 \%$ areas of the country. In the mountain, for example, there are many micro regions with differing conditions with respect to temperature, moisture, humidity, sunshine hours, rainfall, aspects and vegetation sustained over such varied agroecological environments. For instance, a crop variety suitable for one microclimate may not be suitable for another, and the transferability of agriculture technology is limited in such varied microclimatic conditions. Agriculture presents the highest potential for growth and poverty alleviation for the vast majorities of people especially of the poor who live in rural areas. However, systems in Nepal are complex and one change in the system has a multiplier effect on the other systems as well. Terai covers $15 \%$ plain area of the country and it has high potentiality of commercial agriculture production.

Nepalese agriculture should compete with highly subsidized and prioritized agriculture of the two giant neighbors. This has left Nepalese farmers in cross road of tough competitors that has made Nepal almost dumping site of cheap agriculture produce of India and China. This is making Nepal fully dependent on import of consumable agriculture commodities 
which can be produced abundantly within the country. There are a number of key issues and challenges of agriculture which are pivotal to address are outlined herewith.

\section{a. Population growth}

In 2013/14, there was a rapid population growth with a growth rate of $1.35 \%$ per annum and with a population density of 180 per square kilometer (Population census, 2011) amidst a scarce supply of fertile land that has led to intense pressure on the natural resources. As a result, encroachments in the marginal lands for agricultural use and conversion of prime agricultural land to other non-agricultural uses have started signaling grave environmental repercussions across the country. Agriculture growth rate in the past barely kept pace with population growth rate, and per capita gains were insignificant. Consequently, agriculture faces a tremendous challenge of feeding some 27 million people in Nepal being instrumental to her prosperity. This requires modernization and commercialization of agriculture through science led R\&D of appropriate technologies and knowledge to address rural poor, disadvantaged, and marginal farmers.

\section{b. Poverty and unemployment}

In $2013,70.1 \%$ of total household expenditure went toward food purchase against world average of $38.3 \%$. The comparable figure in the U.S. was in the range of $7-14 \%$. This figure for Nepal is among the highest in the world after the Democratic Republic of Congo and Cambodia where total household spending on food was higher than $70 \%$ (The Economist Intelligence Unit, 2013). Around 70\% of the remittance earned by the massive migration of unskilled youth mostly in Gulf countries and Malaysia is spent on food and consumable commodity in Nepal (Nepal Economic Outlook, 2013). As a predominantly agricultural country with a small manufacturing sector, economic activities and jobs in the non-agricultural sector are limited. Unemployment and underemployment is a major problem, particularly among urban youths. With the expansion of the services sector, educated and skilled are finding jobs in education, banking, and financial and health sector. However, the growth in these sectors is not enough to absorb the number of college graduates each year. Although foreign employment has grown at a record pace in recent years, it does not address high urban youth unemployment problem and chronic poverty particularly in rural areas.

Poverty in Nepal is mainly a rural phenomenon and rural people are more isolated from basic developmental services. As of now around 6.5 million people (25.16\%) are below poverty line in Nepal (http://sapkotac.blogspot.com/2013/07/poverty-by-district-innepal.html) among them there is vast majority in mid and far western regions where there is an acute food shortage. Hunger and poverty is rife in those regions. People in Nepal particularly those who live in geographically remote areas are more poor and vulnerable and also isolated from access to basic needs and services of essential goods and commodities. Because of rampant poverty and unemployment, Nepalese youths, mostly 
unskilled and uneducated from rural area have been flooding to Gulf countries, Malaysia and other countries in search of menial jobs. As a result remittance inflow to Nepal has become one of major sources of GDP $(25 \%)$ to the country.

\section{c. Low investment in agriculture}

Currently there is limited and declining public funding for agricultural despite its potential contribution to agricultural development and economic growth in Nepal. Investment in agriculture is low compared to neighboring countries of SAARC and ASEAN region. Due to food shortage of 2008 there is a surge of investment for agriculture globally; however Nepal's investment in agriculture increasing with snail pace in recent years (Fig. 1) compared to its contribution to national GDP. At least there should not be less than 5\% of total national budget outlay of expenditure on agriculture to reduce trade deficit and create employment in rural areas in the country. Low investment in agriculture has created slackness in technology generation and advancement in science led development of agriculture thereby appropriate technologies to meet the need of diverse clients are limited. Furthermore, agro-ecological and socioeconomic diversity have further increased demand for technologies to meet the needs of poor and disadvantage groups in remote and isolated regions (e.g. Karnali, high hills, tran-Himalayan region, and interior parts of Terai) in the changing socioeconomic context. Budget expenditure for agriculture in Nepal shows that there was no consistency for giving priority to agriculture despite its importance in National economy. It could be the reason why there is even food insecurity in a country where more than one third of GDP comes from agriculture sector.

The figure 1 below seems to be actual expenditure. It will be good to show percent of AGDP or percent of National Budget to clearly justify this section.

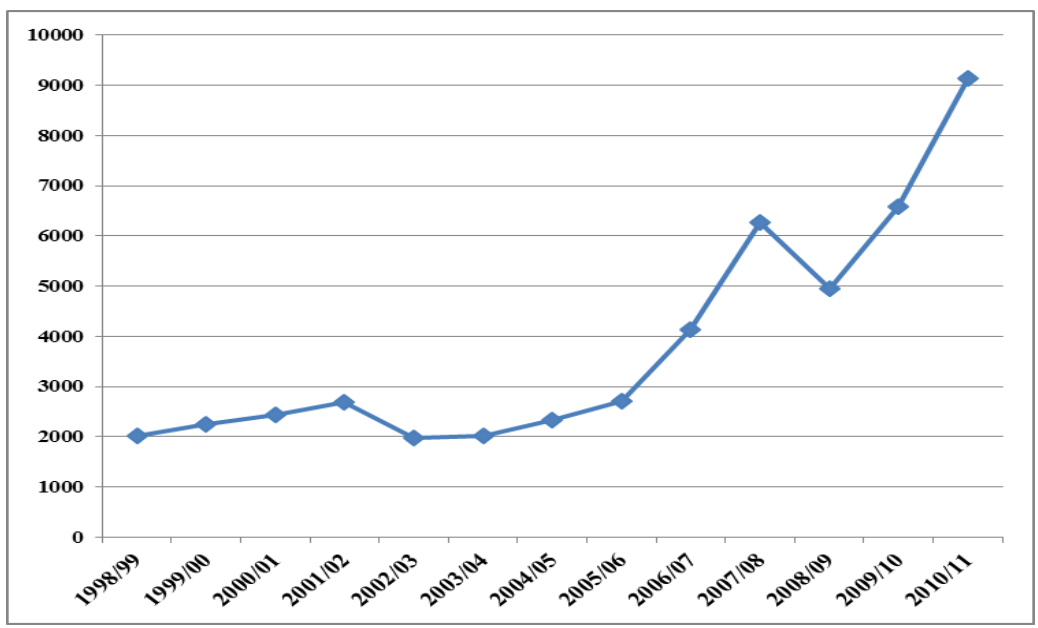

Fig. 1 Budget expenditure (NRs million) in agriculture during 1998/99-2010/11 in Nepal

Source: Nepal Rastra Bank 


\section{d. Yield gaps, food shortage and subsistence farming}

In Nepal, national census report of 2001/02 stated that only $40 \%$ of the household have food for the whole year, 13\% of the household have enough food for 3 months and $26 \%$ have food for only 4-6 months of the year (Dhital, 2009). Food shortage in Nepal has been a common phenomenon and WFP reported that in 39 districts out of 75 districts food shortage has becoming alarming and people are dying of starvation in mid and far western hilly districts.

Khadka (2008) presented an alarming situation of food crisis and implication on sustainable agriculture; food prices could increase in coming days and prices of wheat and rice, the most important staples increased by $68 \%$ and of the maize by $77 \%$ within 2008 . World Bank in 2008 reported that food crisis of the period was termed as a silent Tsunami where a $20 \%$ arisen in food prices pushed 100 million people back into poverty; a $1 \%$ rise in food prices causes $0.5 \%$ less energy intake among poor, and food price hiked by $21 \%$ since 2006. To cope up with such ravaging condition of food shortage and price rise of edibles has raises serious concern to remote and inaccessible areas of hills and mountains where agriculture is the main stay of people in Nepal. In Nepal, almost $40 \%$ population go in a low calorie intake and their food consumption is merely sufficient for 3-6 months and there is a deficiency of 0.15 million ton of food annually (The Gorkhapatra, Daily, 16 October 2009).

The implication of these scenarios hold true in Nepal particularly in the hills due to its nature of subsistence farming, scattered parcel of land and low holding of land which is 0.6 ha per family. Farm level productivity of most of food crops and livestock is low and fall below $50 \%$ of the attainable potential than that of experimental plots. For example the average attainable yield of major staple crops is $4-6 \mathrm{t} / \mathrm{ha}$ and the national average is around 2.5-3.0 t/ha (MoAD, 2014) where as yield gap is almost double of the national average (Fig. 2). This indicates that there is a wide yield gap between attainable yield and farmers' yield. Agriculture RforD should focus attention to bring down yield gap through functional strategy of technology development and transfer in public-private-partnership approaches in order to sustain food security and enhance rural livelihood. In addition, low productivity and lack of competitiveness are due to not only gaps in yield, but also in knowledge, information and linkages between research and extension which has hindered flow of information and technologies. 


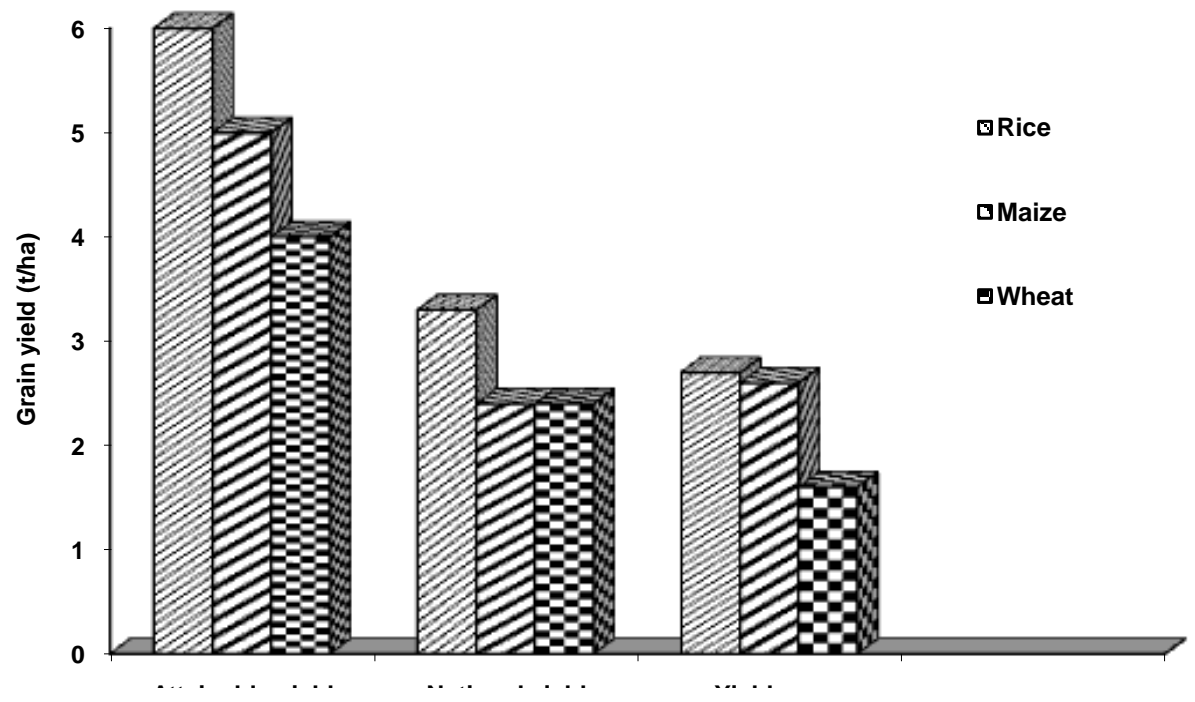

Fig. 2 Yield level comparison of major cereals in 2013/14

A fifteen year's (except four years) from 1999/00 to 2013/14 edible food production, requirements and balance sheet of Nepal indicates a positive balance of food grain production in the country (Table 1). Nepal's agriculture is predominantly rainfed and food deficient years are the result of unfair rainfall during main crop season. Meaning to say that if monsoon fails there would be failure of agriculture which will jeopardize all the development efforts of government. To mitigate such a challenge there is much to do to reduce hunger and malnutrition in the country by giving emphasis on agriculture research on rainfed agriculture systems. 
Table 1. Edible cereal grain production, requirement and balance in Nepal (1999/002013/14)*

\begin{tabular}{llll}
\hline Fiscal & \multicolumn{3}{c}{ Edible cereal grain (mt) } \\
\cline { 2 - 4 } Year & Total production & Requirements & Balance \\
\hline $1999 / 00$ & 4451939 & 4383443 & 68496 \\
$2000 / 01$ & 4513179 & 4430128 & 83051 \\
$2001 / 02$ & 4543049 & 4463027 & 80022 \\
$2002 / 03$ & 4641466 & 4565820 & 75646 \\
$2003 / 04$ & 4884371 & 4671344 & 213027 \\
$2004 / 05$ & 4942553 & 4779710 & 162843 \\
$2005 / 06$ & 4869440 & 4890993 & -21553 \\
$2006 / 07$ & 4815284 & 4995194 & -179910 \\
$2007 / 08$ & 5195211 & 5172844 & 22367 \\
$2008 / 09$ & 5160000 & 5293000 & -133000 \\
$2009 / 10$ & 4984987 & 5367119 & -382132 \\
$2010 / 11$ & 5570019 & 5235551 & 334468 \\
$2011 / 12$ & 6020295 & 5077134 & 943161 \\
$2012 / 13$ & 5648265 & 5239827 & 408438 \\
$2013 / 14$ & 6085776 & 5295886 & 789890 \\
\hline
\end{tabular}

*Source: MoAD

Likewise, belt wise food availability of cereal crops in 2013/14 (Fig. 3) indicates that over all food availability in Nepal is almost balanced; however there is a chronic food shortage in the mountains, specifically of mid and far-western mountains and hills (not shown in detailed).

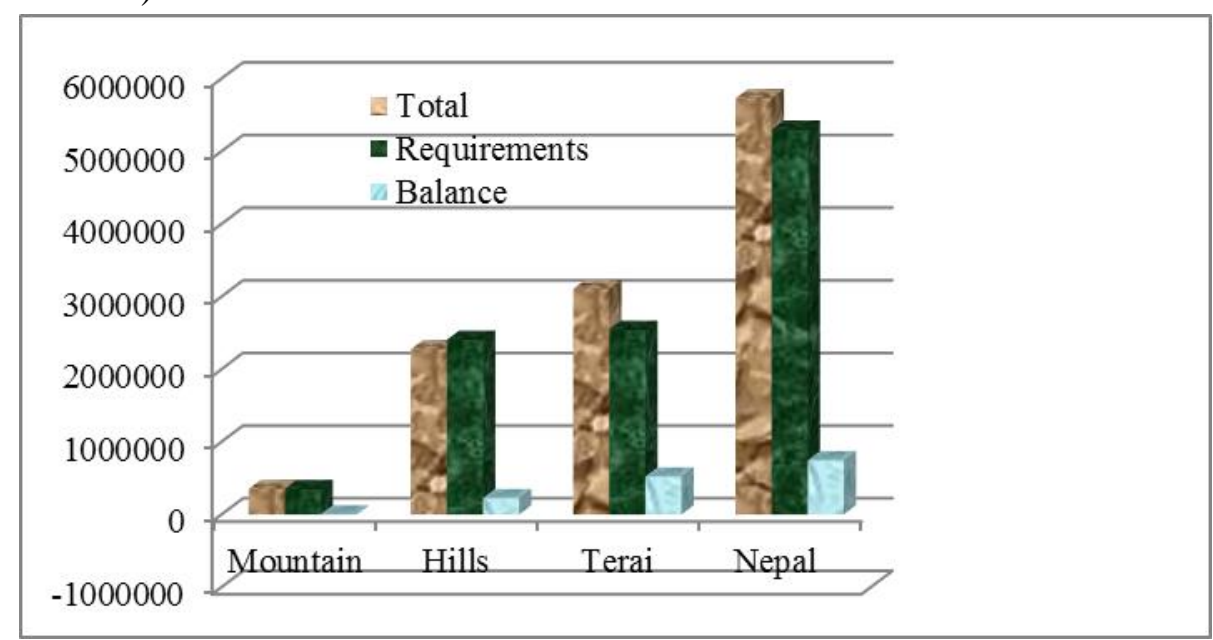

Fig. 3 Belt wise edible cereal grain availability, requirement and balance (mt) in 2013/14

Source: MoAD 
Therefore more emphasis should be given to make food sufficiency in the hills and mountain particularly for mid and far western regions which is very challenging for these regions which varies ago-climatically and having fragile, remote and inaccessible. Food shortage is rampant across the country even in the Terai, the food bowl, where there is reported food deficiency in 2013/14.

\section{e. Poor linkages between technology generation and dissemination}

The major concern for present agricultural development systems is ineffective link between technology generation and dissemination among public and private partners. Ineffective links has impeded the development and transfer of technology to improve the livelihood of farming community and stimulating the agricultural development of the country. Bridging the gap between research and development agencies is the most serious institutional problem in developing effective technology development systems in the country. Technologies are introduced in Nepal by international, regional, and local networks of research activities. Linkages and coordination in the sector has taken an added significance in light of Nepal's greater integration into regional and international markets. Although linkage mechanisms between research-extension and private sectors including I/NGOs has improved in the recent years, the major concerns for agricultural development in Nepal is still of poor program level functional linkages between research and extension. Functional links among agricultural research institutes, extension and other development agencies (NGOs, CBOs) are important for successful technology development and delivery to boost production of agriculture commodities.

This has hindered commercialization of agriculture in niches where there is ample room for raw material production of agro-based industries such as sugar factory, jute mills, tea industries, vegetable seed production and many horticultural commodities of flowers, fruits, vegetables and agro processing and post harvest related industries. Technology to tackle such concern should go hands in hands for boosting agro-based industrialization.

\section{f. Subsidy removal on agricultural inputs}

Government of Nepal since late nineties removed subsidies to agricultural inputs such as seed fertilizer, implements, and other factors of production. This has created high cost of production resulting to reducing competitive capacity of Nepalese farmers. Nepal, one of the signatories of World Trade Organization (WTO) presumes that there should be a free flow of agricultural commodities in the country and Nepalese farmers lost competitive abilities with respect to other advanced countries which further aggravated the food deficit in the country. However, subsidies on agriculture remained a prime importance of government of other neighbouring countries such as in India. This again helped lose competitive ability of Nepalese agriculture as Nepal has limited subsidies and support in 
agricultural inputs. Because of high cost of production has already resulted serious consequences of low purchasing power of poor Nepalese farmers who live under extreme poverty of earning less than a US dollar per day. The consequences of such a wrong decision of lifting inputs subsidy by the Government of Nepal has resulted serious consequences in the Nepalese agriculture which has left marked effect of poverty and food shortage.

\section{g. Fast depletion of natural resources}

There is declining soil fertility, loss of land due to land sliding, erosion and deforestations which are causing problem of soil fertility and water management. Forest and pasture resources in Nepal are depleted by overgrazing and improper land and forest management, excessive mining of sand, gravels, boulders in Churiya regions and foot hills where road accessibilities are opened up causing fast depletion of natural resources including illegal logging and depleting of wild life reserve. As a result, there is heavy soil erosion in hills and slope and desertification and flooding in the plain making fertile land unfit for agriculture management. Other factors of natural resources depletion are land sliding; floods, drought and rising prices for food, energy and other inputs.People residing in the Churiya are police without uniform. Churiya and other fragile regions of Nepal could be conserved by the active involvement of people residing there since time immemorial. Livelihood of people is directly dependent on effective management of natural resources available in the regions where people are closely maintaining agro-ecology surrounding them. Conservation of natural resources and livelihood of people should go hands in hands in a way natural rersources management is done scientifically by the present generation without compromising the needs of future generation as well.

\section{h. Labor scarcity and limited trained human resources}

Nepalese agriculture is not mechanized in a way that should fit for agriculture industrialization. Whatever production from agriculture is obtained it is based on highly labor intensive. It is, therefore, in one hand there is a dearth of skilled labor in agriculture and in the other hand there is equally deficiency of trained human resources in this sector for industrialization. Ultimately these have led to slow pace of agriculture resulting to hinder in agriculture industrialization. Basnet et al (2014) have explained that each year from Nepal more than 4 million Nepalese travel abroad for work, the majority to India and the Gulf. It has been suggested that these migrant labor have sent remittance home could account for as much as 33 percent of GDP, providing crucial household income, and are responsible for more than half the reductions in poverty over the past 20 years (Basnet et al; 2014). This has created labor shortage in many sectors such as industry, construction of infrastructures including roads, buildings, and highway in general and agriculture in particular. One can see many ferlile lands of hills, mountains and even in Terai left fallow 
without production due to shortage of labor. The other lacuna of shortage of trained manpower and labor in agriculture is the slow or no industrialization of this sector resulting to high import of agriculture commodities from scarce currency earned by the labor working in gulf countries and Malaysia. Whatever money is incurred for importing agriculture commodities could be utilized by producing consumable agriculture commodities within the country. This could improve trade surplus and enhance agroindustry in the country provided out migration of labor is checked and skilled manpower is developed in the country. These are not happening in the present context which are one of the most pre-requisites for agro-industrialization and reduce huge trade deficit.

\section{Prospects of agriculture industrialization}

Nepal is culturally an agriculture country. Until and unless agriculture is not given functional priority by the government, Nepal could not prosper in days ahead. There are immense prospects to enhance industrialization of agriculture commodity in Nepal. Some ground works should be initiated to ignite agriculture industrialization in Nepal. Food selfsufficiency, poverty reduction, employment generation, export promotion, and import reduction could be attained only through agriculture commercialization. There are immense opportunities of industrialization for agriculture due to geographical location of between two giants Asian countries; India and China, Nepal having favorable climatic condition for commercialization of agriculture commodities that have comparative advantage of producing demand driven agriculture commodities by these countries. Followings are the some of the important prospects and concerns to be addressed to the commercialization of agriculture sector in Nepal.

\section{a. Basic infrastructure development}

Agriculture is a complex phenomenon and its development rests on infrastructure development by supporting allied sectors. To enhance products of comparative advantage such as crops, horticulture commodities (fruits, vegetables and vegetable seeds), nontimber forest product (NTFP) such as Yarcha gumba, Kutki, Panchaunle, saffron, mushroom, tea, coffee, medicinal herbs, handy craft product and many more, and livestock product (meat, milk and milk product, carpet and pasmina wool production) there needs construction of storage facilities, ware house, cold storages, and market development in potential niches along with technology development for these commodities. Aside from this, a good network of link road connecting north-south corridor for linking hills and mountains with Terai and valley floor are necessary prerequisite of basic infrastructure development. To exploit agriculture for reducing poverty there is a need to support other allied sectors. Hazell and Thorat (1999) had shown a unique case of India how number of poor has been decreased per million investments on different sectors that have synergic effect on agriculture (Table 2). This suggests that there is the evidence of investment on 
these areas which can yield relatively high rates of economic return and also significantly lessen poverty and environmental and resource degradation.

Nepal does not have sound basic infrastructure for favoring commercialization of agriculture massively. Experience shows that commercialization of agro-based industry should be supported by the investment on basic infrastructures such as strong research and development systems, construction of irrigation channel, link roads, and power which should be staked by strong education systems, power supply, soil and water conservation, other basic rural development strategy coupled with proper health facilities of its citizen for yielding targeted out puts (Table 2). There is a need to invest heavily on these infrastructures for a tangible output in agriculture through commercialization in modern Nepal.

Table 2. Incremental effects of government spending on poverty, India

\begin{tabular}{lll}
\hline Investment sector & $\begin{array}{l}\text { Decrease in number of poor, } \\
\text { per million Rupees spent }\end{array}$ & \\
\hline Research and Development & 91.4 & 2 \\
Irrigation & 7.4 & 5 \\
Roads & 165 & 1 \\
Education & 31.7 & 3 \\
Power & 2.9 & 7 \\
Soil and Water & 6.7 & 6 \\
Rural Development & 27.8 & 4 \\
Health & 4 & 6 \\
\hline
\end{tabular}

Source: Fan et al (1999)

\section{b. High priority for agriculture and niche specific commodity}

There is food shortage in mountain and hills due to limited agriculture land for cereal crop production specially rice, wheat and maize. These commodities having comparative advantages should be promoted as income generating activities in the region where there is a high possibility of producing these commodities. There are commercially viable alternatives in the high hills to cope up with food shortage which include animal husbandry (sheep, goat, and yak farming) for wool, meat and milk and milk products. Emphasis on non-timber forest product (NTFP) comprising of Yarsha gumba (Pordesia sinensis), and locally available medicinal herbs such as Panch aunle, satuwa, Xanthoxylum, Seabuck thorn, Morchella and other medicinally important mushrooms and many more should be commercially cultivated. These commodities have comparative advantages for maintaining sound environment giving local employment for youth who are going to gulf and other countries in search of menial jobs that is risky, difficult and dangerous for unskilled manpower of Nepal. These are unique commodities with comparative advantage that can generate local employment leading to increase in purchasing power of the people for 
sustaining livelihood in the reason in one hand and on the other hand once potentiality of niche specific commodities is harnessed there are wide scale opportunities for tapping other such viable enterprises by the entrepreneurs themselves.

Nepal's investment on agriculture is poor compared to South Asian countries. An illustration to this effect to attain national and household food security how much investment in agriculture is needed to attain an AGDP in two different scenarios has been illustrated (Table 3). The declining investment in agriculture amounts to utter negligence and indifference to the needs of the poor, especially the resource-poor farmer (Singh, 2009). He further highlighted that investments in agricultural R\&D and agriculture have paid off handsomely, with an average internal rate of return of about 40 percent and have been highly pro-poor and investment in agricultural R\&D tripled in China and in India over the past 20 years, it increased only slowly in most other countries. For these countries, sharply increased investment and regional cooperation in $R \& D$ are urgent to bridge productivity, income and development gaps.

Table 3. Required investment in agricultural $R \& D$ to attain food security and to reduce poverty and hunger in South Asia* (Current price in million US\$)

\begin{tabular}{|c|c|c|c|c|c|}
\hline \multirow{2}{*}{$\begin{array}{l}\text { Country } \\
\text { Scenario } 1\end{array}$} & 2002 & 2010 & 2015 & 2020 & 2025 \\
\hline & \multicolumn{5}{|c|}{$2.14 \%$ agricultural growth (to attain national food security) } \\
\hline Bangladesh & 101.2 & 143.0 & 177.5 & 220.3 & 273.5 \\
\hline India & 1258.3 & 1778.0 & 2206.9 & 2739.3 & 3400.0 \\
\hline Nepal & 24.1 & 34.2 & 42.4 & 52.6 & 65.2 \\
\hline Pakistan & 158.8 & 224.4 & 278.5 & 345.7 & 429.2 \\
\hline Sri Lanka & 47.4 & 66.9 & 83.1 & 103.1 & 128.0 \\
\hline South Asia & 1589.8 & 2246.4 & 2788.3 & 3461.0 & 4295.8 \\
\hline Scenario 2 & \multicolumn{5}{|c|}{$\begin{array}{l}\text { 4\% agricultural growth (to attain household food security and alleviation of } \\
\text { poverty and hunger) }\end{array}$} \\
\hline Bangladesh & 101.2 & 162.1 & 217.6 & 292.3 & 392.3 \\
\hline India & 1258.3 & 2015.6 & 2705.8 & 3632.6 & 4876.5 \\
\hline Nepal & 24.1 & 38.7 & 52.0 & 69.7 & 93.6 \\
\hline Pakistan & 158.8 & 254.3 & 341.5 & 458.4 & 615.5 \\
\hline Sri Lanka & 47.4 & 75.9 & 101.9 & 136.7 & 183.5 \\
\hline South Asia & 1589.8 & 2546.7 & 3418.8 & 4589.7 & 6161.4 \\
\hline
\end{tabular}

*Source: Singh, 2009, APAARI

\section{c. Efficient land management}

In Nepal, management of land, the most important resource, is associated to both at the farm level and the community level. The farmer focuses on the management of private lands, while the latter is concerned with the management of public land resources. Building of terraces in sloppy and irrigated tracts is one of the most important soil conservation activities that have been going on for centuries. In the areas, farmer responses to increasing 
shortages and difficulties of fodder and fuel have been to plant more fodder trees and grasses on private fields, stall feeding of animals, sharing of livestock rearing and products, reduction in the number of livestock, use of agricultural residues for burning, and wherever available, and use of chemical fertilizers are directly or indirectly linked with land management for agriculture in Nepal.

For commercialization of agriculture, fragmented land parcels and small holdings should be consolidated because land fragmentation and settlement in fertile agricultural land of valley and Terai has been encroached for purpose other than agriculture. Land is the basic important factors of production for agriculture, industrialization and other non-agricultural purposes. In order to address agriculture industrialization, strong land policy for agriculture and non-agriculture purposes should be clearly delineated otherwise there is less likelihood of supplying raw materials for agro-based industries in the country. Strong and implementable land planning and zoning policy should be endorsed and effectively implemented to address food self-sufficiency and reduce increased trade imbalance in general and agriculture based commodity in particular.

\section{d. Import substitution and comparative advantage}

Nepal has different types of agro-climate suited to growing many types of crops and raising animals. There are places of unique micro environment in very short vertical distance. Such micro climatic variation favors comparative advantage of growing off season crops in the hills where there is high demand of such commodities in the plain and urban area. Main season in the hill becomes off season for the same crops in Terai and valley floor. Commodities grown in valley floor can be grown in the hills as off season. Examples of off-season crops in the hills are cole crops (cauliflower, cabbage, broccoli, kale, turnip), potato and tomato could be observed during rainy season (potato during FebJul, cole crops May-August). Because of comparative advantages of micro climate, vegetables, fruits, condiments and species grown in the hills of Nepal have now been highly demanding during rainy season in far flung market of Indian subcontinents including Bangladesh and Middle East. If such opportunities could be tapped, hill agriculture could provide employment and income generation for rural youth and reducing labor migration. These are such enterprises which could be tractable for reducing hunger and poverty in Nepal.

Comparative advantages of hills and mountain where there is temporal and spatial variation in micro climate is a boon for year round fresh vegetable and flower production. This is golden opportunity for agriculture commercialization of these commodities in Nepal. Aside from this the taste and aroma of agriculture commodities produced in micro environment of Nepal has unmatched market across the globe. Lentil exported to Bangladesh has increased demand for its unique taste. Similarly, organic tea and coffee 
produced in Nepal have high demand in Europe and USA. So is the case with large cardamom which is called "Himalayan Viagra" in Arab and western countries. There is a high demand of locally produced rice, turmeric, ginger and organic vegetables even within the country. Vegetable seed, mandarin orange, sweet orange, sour lime, red pepper, fresh pea, kidney beans, mountain goat, cut flowers, honey, apple and temperate fruits (peach, plum and apricot), cheese, mush room and milk and milk product, native poultry, and organic food have high demand within and outside the country. The problem is that there are no serious efforts to increase sufficient quantity of these produce in Nepal. This could have multiplier effect of generating employment and income in the country thereby out flow of youth force in search of mostly agriculture related jobs in other countries could be minimized and country could be in line of self-sufficiency in food production and industrialization.

There are very prominent agriculture commodities having potentiality of export promotion in the country, however much of the scarce foreign reserve has been spent to import these commodities especially from India (Table 4) and other countries (Table 5). India has almost similar agro-climatic zones to that of Nepal. Except some tropical crops of palm, coconut, cashew nut and some NTFP products that include spices and condiments, Nepal can grow all of the imported commodities listed in the above tables. This clearly implies that Nepal is headed towards dependency even for agriculture commodities. One can cite the example of rice imported from India in 2012/13 against 2011/12 by an increase of $98.2 \%$ and again surge of rice import by $46.4 \%$ in $2013 / 14$ (Table 4). This is a horrible example of dependency in import of rice, the number one commodity and staple food of Nepal. It is shameful to be an agriculture country where rice is not only a staple but also a pride of nation and a sign of prosperity for Nepalese farmers because when rice is culturally, socially and economically associated from cradle to death for Nepalese people. Of the 19 commodities listed in table 4, except chemical fertilizer, insecticides and cumin (can be produced in high mountains) all other commodities could be comfortably produced in Nepal. There is a total increase of $26.6 \%$ and $28.8 \%$ import of these agriculture commodities from India in 2012/13 and 2013/ 14.

Of the 11 commodities included in the table 5, only beetle nut, palm oil, clove, raw silk, small cardamom and insecticides could not be commercially produced in Nepal. Like the increase in import of agriculture commodities from India increase in total import of these agriculture commodities from other countries in 2012/13 was $90.2 \%$ and 2013/14 was $14.8 \%$. This again suggests that Nepal is prime location of export of agriculture commodities from India and other countries despite the fact that these commodities can easily be produced in Nepal and there is a big market of agriculture commodities to be imported from hard earned remittance of unskilled labors of Nepal working in scorching heat of Gulf and Malaysia. 
Table 4. Imports of major agriculture commodities in Nepal from India during 2011/12 - 2013/14 (NRs in million)*

\begin{tabular}{|c|c|c|c|}
\hline Commodity & 2011/12 & $2012 / 13$ & 2013/14 \\
\hline Chemical fertilizers & 4506.5 & 8485.5 & 8025 \\
\hline Tobacco & 1916.8 & 2068.2 & 2133.8 \\
\hline Vegetables & 2589.5 & 4548.6 & 6191.1 \\
\hline 4. Paper & 2278.1 & 3678.3 & 4811.5 \\
\hline 5. Rice & 4267 & 8455.8 & 12379.4 \\
\hline 6. Baby foods \& milk products & 979.1 & 3599.6 & 4827.4 \\
\hline 7. Sugar & 99.4 & 1061.2 & 59.7 \\
\hline 8. Insecticides & 942.4 & 1102.7 & 1444.7 \\
\hline 9. Fruits & 857.6 & 1305.1 & 2255.5 \\
\hline 10. Cumin seed \& pepper & 702.3 & 1160.2 & 1274.4 \\
\hline 11. Incense sticks & 272.3 & 553.5 & 772.1 \\
\hline 12. Live animals & 422.9 & 1005.9 & 1466.2 \\
\hline 13. Raw cotton & 61.6 & 357.4 & 255.8 \\
\hline 14. Tea & 29 & 50 & 46 \\
\hline 15. Molasses sugar & 49.7 & 74.6 & 60.7 \\
\hline Total & 299389.6 & 367031.2 & 472730.6 \\
\hline
\end{tabular}

*Source: Nepal Rastra Bank

Table 5. Import of major agriculture commodities in Nepal from other countries during 2011/12 - 2013/14 (NRs in millions)*

\begin{tabular}{lllll}
\hline Commodity & $\mathbf{2 0 1 1 / 1 2}$ & $\mathbf{2 0 1 2 / 1 3}$ & $\mathbf{2 0 1 3 / 1 4}$ \\
\hline 1. & Crude soybean oil & 9662.3 & 10627.5 & 14778.5 \\
2. $\quad$ Beetle nut & 1639.2 & 2774.6 & 7382.6 \\
3. $\quad$ Raw wool & 657.2 & 1050.1 & 1454.3 \\
4. $\quad$ Chemical fertilizer & 2291.3 & 4838.7 & 6082.7 \\
5. Edible oil & 2794.1 & 2606 & 2352.3 \\
6. Palm oil & 312.6 & 353.2 & 429.1 \\
7. Small cardamom & 286.9 & 603.4 & 724.7 \\
8. Powder milk & 300.7 & 207 & 127.1 \\
9. Insecticides & 206.7 & 194.8 & 174.5 \\
10. Raw silk & 0 & 147.9 & 314.2 \\
11. Clove & 19.6 & 24.9 & 62.9 \\
Total & 162278.1 & 189709.1 & 236031.2 \\
\hline
\end{tabular}

*Source: Nepal Rastra Bank

\section{e. Export promotion}

There are plenty of agriculture commodities having export potential to India and Other countries (Table 6, Table 7). Among these commodities, Nepal has comparative advantage and high scope of exportability of these commodities to India namely; ginger, herbs, Ayuvedic medicines, pasmina, brooms, pulses, vegetables, large cardamom, turmeric and many others (Table 6). Ginger, pulses, large cardamom, broom, raw jute and pasmina are 
some of the topmost items to be exported even globally from Nepal. However, despite having so much of importance of export potentiality of these commodities, there is a negative growth of these items so far as export to India is concerned. For example herbs in $2013 / 14$ was negative $22.1 \%$, turmeric negative $62.1 \%$, pasmina negative $0.2 \%$, brooms negative $53.2 \%$ and many more compared to previous year and so is the case in 2012/13 compared to year 2011/12 as well (Table 6). On the other hand, almost $70 \%$ of the hard earned remittance has been spent heavily on consumable agriculture commodities that are mostly imported from India.

Table 6. Export of major agricultural commodities to India (NRs in million) during 2011/12 -2013/14*

\begin{tabular}{clll}
\hline Major commodity & $\mathbf{2 0 1 1 / 1 2}$ & $\mathbf{2 0 1 2 / 1 3}$ & $\mathbf{2 0 1 3 / 1 4}$ \\
\hline 1. Jute sacks & 2102.4 & 3671.1 & 3578.6 \\
2. Juice & 3027.1 & 3801.6 & 4431.5 \\
3. Oil cake & 642.7 & 637.6 & 702.9 \\
4. Jute hessian & 1094.5 & 0 & 5.6 \\
5. Ginger & 386.9 & 1311.6 & 451.7 \\
6. Herbs & 89.9 & 313.4 & 244.1 \\
7. Ayurvedic medicine & 848.3 & 671 & 894.7 \\
8. Cardamom & 3275.5 & 3849.6 & 4267.2 \\
9. Rice bran oil & 191.1 & 133.9 & 195.4 \\
10. Clarified ghee & 371 & 135.8 & 155.9 \\
11. Bran & 70.5 & 187.5 & 181.5 \\
12. Raw jute & 0 & 43.7 & 43.7 \\
13. Pashimina & 41.6 & 55.3 & 55.2 \\
14. Brooms & 74.8 & 2.6 & 1.2 \\
15. Paper & 6.4 & 0.5 & 0.1 \\
16. Pulses & 202.5 & 0.9 & 3.8 \\
17. Cinnamon & 63.1 & 49.8 & 64.5 \\
18. Vegetables & 68.1 & 72.5 & 122.8 \\
19. Handicrafts goods & 73.2 & 22.1 & 20 \\
20. Mustard \& linseed & 6.3 & 2.9 & 17.5 \\
21. Fruits & 2.7 & 9.9 & 16.2 \\
22. Turmeric & 2.2 & 11.7 & 4.4 \\
23. Biscuits & 0 & 0.5 & 1.5 \\
Total & 49616 & 50999.8 & 59417.3 \\
\hline Source: Nepal Rastra Bank & & &
\end{tabular}

* Source: Nepal Rastra Bank

Export of agriculture commodities to other countries has been found for eight commodities (Table 7). There is the ample room to produce these commodities organically for which a vast market in overseas countries is waiting crazily because of health concerns of citizens in these countries. Micro environment of Nepal is largely favorable for producing these commodities and Nepal as a whole could be a unique place for organic produce because Nepal does not have single gram of chemical fertilizer production and whatever fertilizer is used it is totally imported from other countries. Even for such highly potential export 
commodities Nepal has negative growth of these commodities. In 2012/13 there was negative export of these commodities compared to previous year for example negative $58.4 \%$ for Nepalese paper and paper products, negative $95.5 \%$ for herbs, negative $10.7 \%$ for tea, negative $48.8 \%$ for pasmina and negative $12.4 \%$ for woolen carpet compared to previous year (Table 7). Likewise in 2013/14 there was export of negative $23.5 \%$ for pulses and negative $9.4 \%$ than that of previous year.

Table 7. Export of major agriculture commodities to other countries during 2011/122013/14 (NRs in millions)*

\begin{tabular}{|c|c|c|c|}
\hline Commodities & 2011/12 & $2012 / 13$ & $2013 / 14$ \\
\hline 1. Woolen carpet & 6938 & 6075 & 7364.7 \\
\hline 2. Pulses & 2497 & 2671.4 & 2043.9 \\
\hline 3. Pashimina & 3230.3 & 1655.2 & 2085.1 \\
\hline 4. Nepalese paper \& paper product & 587.3 & 244.2 & 287.6 \\
\hline 5. Herbs & 197.7 & 9 & 852.8 \\
\hline 6. Tea & 251.8 & 224.9 & 203.7 \\
\hline 7. Readymade leather goods & 100.6 & 212.4 & 206.7 \\
\hline 8. Niger seed & 0 & 0 & 0.2 \\
\hline 9. Other commodities? & & & \\
\hline Total & 24644.7 & 25917.3 & 30875 \\
\hline
\end{tabular}

*Source: Nepal Rastra Bank

Nepalese farmers cannot compete with Indian and Chinese farmers because of heavy subsidy of production inputs provided by government of these countries to farmers, as a result cheap produce from these countries are dumped in Nepal that has hammered production potentiality of farmers in one hand and on the other hand agriculture industrialization in these countries has given upper hand over traditional and subsistence farming in Nepal. To enhance production potentiality of Nepalese agriculture, it is imperative to commercialize agriculture without taking time immediately. Our economy is heavily dependent on import of consumable goods which could be lavishly produced within the country. Export of agriculture commodities to India should be increased not only in double digit but also in triple digit to make Nepal really an agro-based industrialized country for commodities which have high potentiality of production because of favorable climate and big markets within and outside the country.

It suggests that there is no planned investment program of Nepal on agriculture for industrialization in the long run. In the past decades dependency of Nepalese economy was heavily shifted towards remittance from agriculture. Consumerisms on agriculture commodities are primarily dependent on import of items mostly from India and other countries. Nepal has become an ideal place for consumption of food items produced from neighboring countries mainly because of unfavorable agriculture policy of the government. Such situations are not in favor for self dependency and sustaining livelihood of Nepalese 
unless agriculture industrialization is not given priority by the government and people of Nepal.

\section{f. Improvement on foreign trade balance}

Looking after the direction of foreign trade of Nepal with India and other countries presents a cloudy scenario of negative trade balance. During three years' trade balance (Fig. 4) it is anticipated that there is a surge of import from India and other countries against a meager export to these countries from Nepal. Growth volume of total foreign trade balance is negative to Nepal with these countries by 19 to $26.5 \%$ in 2012/13 compared to 2011/12 and in 2013/14 also same pattern of negative trade balance of 25.3 to $30.8 \%$ was observed with these countries than that of previous year. This is an alarming situation of total negative trade balances of Nepal with these countries. This calls for serious consideration to increase export in order to come to the trade balance. It is only possible through exploiting full potentiality of agriculture commercialization of important commodities having demand driven probability in these countries. This has been explained in depth in above discussion as well.

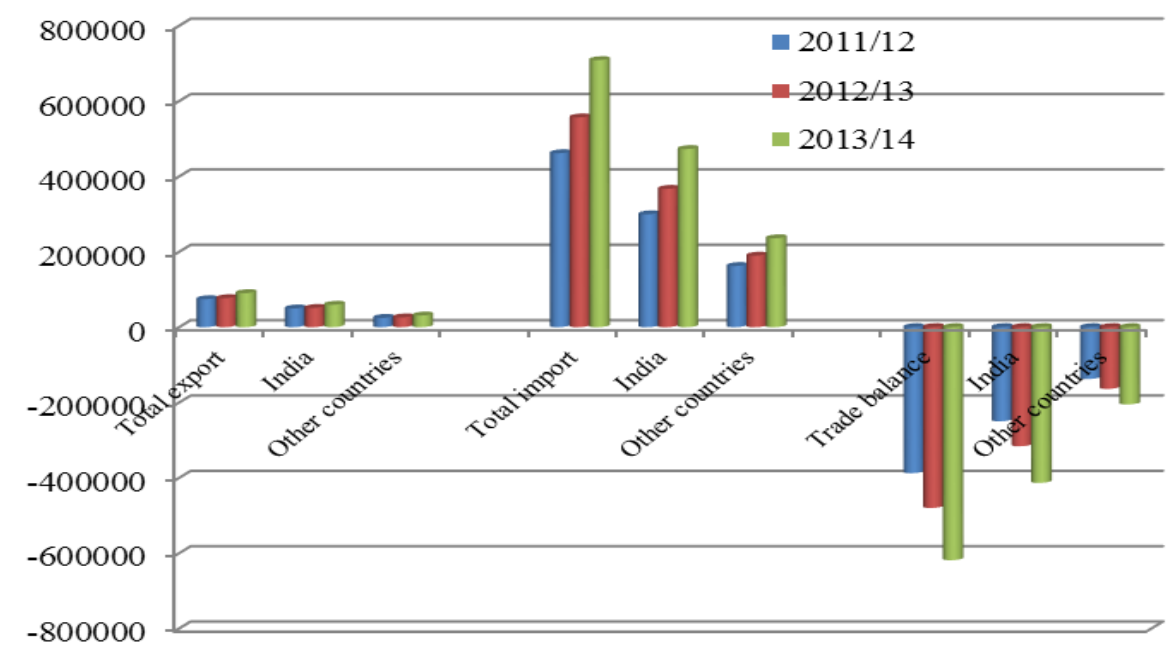

Fig. 4 Foreign trade (NRs in million) during 2011/12 - 2013/14 in Nepal Source: Nepal Rastra Bank

\section{Ways forward for agriculture commercialization in Nepal}

- $\quad$ Present systems of yearly planning for all projects should be changed immediately and project should be prepared and implemented on the basis of periodic plans of short term (one year), midterm (2-3 years) and long terms (more than 3 years). Budget 
and target of achievements should be fixed accordingly instead of yearly budgeting and planning for each and every project.

- The important thing to do for agriculture commercialization is the strong commitment of the government with functional plan and policy of remodeling subsistence agriculture into commercial agriculture aiming to enhance trade balance keeping in minds of the agriculture policy and trade with India and China for increasing competitive capacity of Nepalese farmers by arming them with technology, inputs and market facilities lowering encroachment of middle man and brokers in way agribusiness is one of the profitable enterprises in the open market. This is only possible through chalking out short term, midterm and long term agriculture plan.

- Situation of foreign trade of Nepal does not look satisfactory with respect to sustainability and self-sufficiency. Total trade balance is negatively skewed with these counties. If these situations follow, Nepal's dependency on trade will be completely based on these countries in coming days as well. Thereby Nepalese agriculture and trade will entirely lose its identity in days ahead because total export is very nominal against total import during the period. This has serious consequences on purchasing power and growth of economy compared to big Asian giants of India and China. Therefore, agriculture commercialization and identification of niche specific commodity to give high priority for bringing trade balance by increasing export and reducing import on merchandise in general and agricultural commodities in particular urgently call for due attention of the authorities and policy makers. However, percentile share of total trade export and import to India and other countries seems logical, but in terms of share of ratio of export to import with these counties is many times higher than that of Nepal.

- The issue of negative trade balance, more dependency on import and very small quantity of export are significantly pertinent and serious concerns to be addressed without delay to make Nepal self-sufficiency in foods and reduce massive poverty in the rural areas and check present system of revenue collection based on import and foreign reserve dependency on remittance earned by migrant youths.

- Total convertible reserves in Nepal seem quite impressive although there is an ample amount of increase in inconvertible reserve higher than that of convertible reserve. Increase in inconvertible reserve is not the healthy indicator of national economy (Fig. 5). Growth of convertible reserve in 2012/13 compared to previous year was $12.6 \%$ and this growth continued in $2013 / 14$ by $22.9 \%$ more than in the previous year as well. This indicates that despite heavily depending on import of commodities there is a fair growth of national reserves in the country. This reserve could be channeled to industrialization of agro-based industries for generating employment, income and promoting export to make agriculture sector more viable than ever. This will lead Nepal in the path of self- sufficiency and graduating Nepal from LDC to DC up to 2022 as aimed by the government of Nepal couple of years back. 


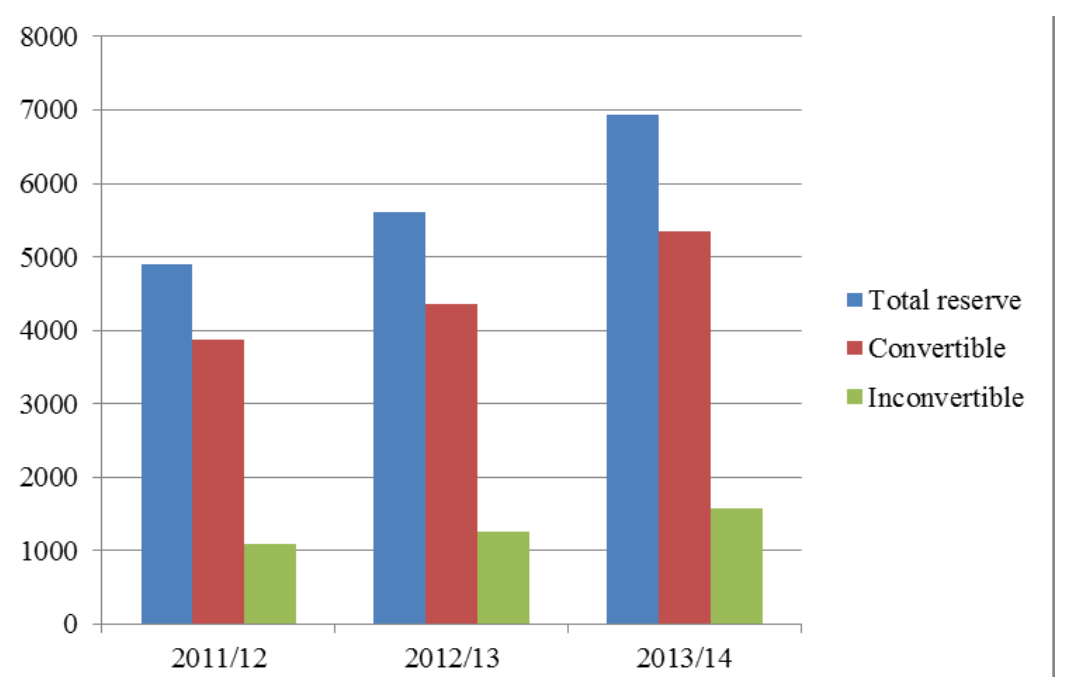

Fig 5. Gross foreign exchange reserve (US dollar in million) during 2011/12 - 2013/14 in Nepal (Source: Nepal Rastra Bank)

- There are number of ways forward to make trade balance by promoting export and reducing imports of agriculture commodities in Nepal. Because Nepal is primarily an agrarian based economy and development is only possible through commercialization of agriculture. Some of pertinent issues have been suggested by Paudel (2006) for efficient agriculture commercialization to make Nepal selfreliance on food, fibers and feed for which Nepal has been spending scarce hard currency mostly earned primarily through unskilled youths working abroad in menial jobs.

- Emphasis on rainfed agricultural technologies to address food insecurity in general and hills and mountain in particular.

- Strong tripartite linkage of research, extension, and teaching with functional relations among extension, teaching institutes, and research systems and CBOs for generation and dissemination technology and development of quality human resources in accordance to the felt need of agro-ecological domains of the country.

- Subsistence agriculture should be remodeled to commercial agriculture by means of science led agriculture technologies.

- Emphasis on low volume high value commodity for import substitution and export promotion such as vegetable seed, processed products and value added and diversified produce.

- Promotion of export oriented commodities of agriculture (carpet wool, cheese, honey, vegetable seed, temperate fruits, mandarin orange, zinger, pulses, and scented rice) and non timber forest product such as Chiraito, Kutki, Panchaunle, tea, coffee, large cardamom, mush room, medicinal herbs, nettle (allo), argheli (raw 
material for Nepali paper production) by backstopping them as basic raw materials for agro-based industries based on these important commodities having comparative advantage through processing and value addition.

- Promotion and utilization of some of the important NTFPs available in hills and mountain deserve special room to generate income and raw material for agroindustrilizations are Lokta (Daphne bholua), Argeli (Edgeworthia gardnerii), Dhasingare (Gaultheria frarantissima), Majitho (Rubia Manjhith), Jhyau (Permalia sps.), Allo (Girardiana diversifolia), Angeri (Loyania ovalifolia), Pakhanbet (Bergania ciliate), Salla cone (Pinus cone), Loth sall (Abis spectabilis) Nagbeli (Lycopodium clavatum), Jatamashi (Nardostachys jatamansi), Sunpati (Rhododendron lepidotum), Kutki (Picrorhiza Kurroa), Sugandawal (Valeriana wallichii), Bikhma (Aconitum heterophyllum Wall. ex Royle), Chiraito (Swartia chirata), Dalchini/Tejpatta, Camphor (Camphor sps.), Datura, Pati (Fumeria palviflora) Hemp, Timur (Xanthoxylum sps.), Yarsha Gumbu (Pordesia sinensis), Merchella and other medicinal mush rooms and many more.

- Local food security by utilizing and managing underutilized and location specific indigenous crops such as fox tail millet (Kaguno), poroso millet (Chino), Amaranthus, buck wheat, oat naked barley, maize, finger millet, sorghum and many other root and tuber crops in food deficit areas of mid and far western regions.

- Paudel et al (2007) have mentioned that food deficiency in hills could be alleviated by giving more emphasis to produce food where production inputs are available easily. They also recommended that seeds should be produced locally in the hills and mountain to minimize transportation cost. Inputs subsidy on agriculture should be regularized to increase competitive ability of Nepalese farmers as well.

- Development of appropriate varieties of crops and breeds of animal (sheep, goat, and rabbit) to meet wool demand for carpet and pasmina (woollen shawl and garments made of down feathers of these animals) industry for export purpose should start R \& D works in the high hills where there are sufficient grazing land. The important commodities in the hills and mountain are yak, sheep, and mountain goat (Chyangra). In such domains emphasis should be given to equip with developing nutritious pasture and grassland in the high hills and mountain wherever possible commercially. Local community will be empowered economically. Animal product such as meat, milk and milk product in the mid hills and high hills will be boosted resulting into generation of income and employment in the hills.

- Hills are very potential for producing high quality temperate and subtropical fruits and vegetables. Fruits and vegetables production in the hills could minimize soil erosion in slopes and terrace that will provide an impetus for off season market in the Terai and road assessable areas in the country. Such agriculture produce could be marketed in the nearby cities of neighboring countries of SAARC region where 
there is a dearth these products for hills have comparative advantage of producing such commodities abundantly as main season product.

- Rural youth have been migrating from the hills to the other parts of the country and abroad in search of jobs. An efficient human development and management systems is needed to give sufficient vocational training to the rural youth, which could be one of the viable alternatives for retaining them in the village. Because they are ones who can bring positive change by their skills in their localities.

- Priority should be given to tackle production decreasing components and constraints such as insect, pests, and diseases in a way by involving local communities and indigenous technologies so as to sustain hill agriculture.

- Rainfed agriculture is the important agriculture in Nepal. Therefore, emphasis should be given to promote rainfed agricultural technologies in the hills.

- Stakeholders engaged to mitigate constraints of agriculture in Nepal should concentrate their efforts to address impact of climate change in hill ecology with respect to sustainability and natural resource conservation efficiently so that hill community residing in the domains in question should feel ownership for managing and utilizing natural resource in a sustainable way.

- Nepal is a micro museum of the world climate and has been affected by the global warming. The consequences of climate change and global warming could be observed in the Himalayas, hills, and Terai ecology of Nepal. The adverse impact of global warming has affected on food production, biodiversity maintenance, and ethnic communities whose livelihood depends upon various food commodities available in the diverse hill ecology. Hence, global warming should be addressed in the pretext of food security and livelihood maintenance of hill ethnic communities.

- Agriculture is one of the most important sectors to enhance livelihood and provide employment to the rural masses in Nepal. Subsistence agriculture should be remodeled to commercial and niche specific comparative advantage based enterprise that would transform Nepalese economy into positive trade balance by promoting export and reducing imports with respect to agro-based commodity. This could be possible through industrialization of agriculture in way ways it supports forward and backward linkages of raw materials and value chain commodities massively in areas with demand driven commodities of the market economy. This will have multifarious effect on transforming subsistence economy into commercial economy. 


\section{References}

Baidhyay, ML. 2066 BS. Rice in Jumla (in Nepali) Hamro Sampada, a monthly publication, year 8, issue 10, Kathmandu, pp 37-38.

Baral., LR. 1996. Looking to the future: Indo-Nepal in perspectives. Retrieved 1 Nov 2015, http://www.gktoday.in/current-article-indias-bilateral-relationships-nepal)/

Bhattarai, KP. 2008. Nepal. Infobase Publishing, New York.

Dhital, Maina.2009. Field report, the Kathmandu post daily, Sep 7, 2009, Kathmandu, Nepal.

Fan, S; PBR Hazell; and S, Thorat. 1999. Linkages between Government Spending, Growth and Poverty in Rural India. Research Report No. 110. International Food Policy Research Institute, Washington, DC as cited by RB, Singh.2009 in Regional Report on Agricultural Research for Development in the Asia-Pacific Region. APAARI and ADB.

http:// www.icimod.org down loaded on 5 Sep 2009.

http://foodsecurityindex. eiu.com/Home/Methodology. The economist intelligence unit, 2014.

http://geography.about.com/library/cia/blcnepal.html, downloaded on 5 Sep 2009.

http://www.flickr.com/photos/happy_sleepy/3503368243/, downloaded on 5 Sep 2009.

http://www.gktoday.in/current-article-indias-bilateral-relationships-nepal)/

http://www.new-ag.info/03-1/focuson.html\#02, downloaded on 6 Sep 2009.

http://www.tradingeconomics.com/nepal/gdp-per-capita-ppp retrieved on 2 Nov 2015.

http://www.travellerspoint.com/photos/stream/size/L/photoID/430079/orderByID/, downloaded on 6 Sep 2009.

Khadka, KR.2008. Food crisis, sustainable agriculture and Nepal (unpubl). A paper presented at the South Asia Regional Conference on Food Crisis, Food Sovereignty and Peasant Rights, 8-9 July 2008, Kathmandu, Nepal.

MoAD (Ministry of agriculture and Development). 2013/14. Statistical Information on Nepalese Agriculture, Agribusiness Promotion and Statistical Division, Kathmandu, Nepal.

Nepal Economic Outlook, 2013/14. 2014. IDE, Kathmandu. Blog, poverty by district in Nepal,

Paudel, MN; B Mishra; NS Thakur; PP Khatiwada; SP Neopane; SM Shrestha (eds.). 2007. A synoptic history of agriculture development and outreach research in Nepal. 2007. Proceedings of the $8^{\text {th }}$ National Outreach Research Workshop, 19-20 June 2007, Kathmandu, Nepal pp 424.

Paudel, MN. 2006. Role of outreach research in transferring agro-technology in Nepal. Paper presented in the Hill Maize Research Project (HMRP)/CIMMYT Partnership Meeting held at RARS, Lumle, Nepal Nov 7-8, 2006.

Paudel, MN and NK Sharma. 2009. Pathway of challenges for hill agriculture systems in Nepal. Proceedings of the Regional Workshop on Hill agriculture in SAARC 
Countries: Constraints and Opportunities, 3-5 November, Dhaka, Bangladesh pp 94-99.

Paudel, MN and NK Sharma. 2009. Prospects and limitations of hill agriculture system in Nepal. Proceedings of the Regional Workshop on Hill agriculture in SAARC Countries: Constraints and Opportunities, 3-5 November, Dhaka, Bangladesh pp 85-93.

Paudel, MN and NS Thakur. 2008.Achievement of outreach research for agro-technology generation and transfer. SAARC Jn. Agri. 6(1), pp 1-10.

Paudel, MN; RP Upreti; RK Neupane; and R Khadka. 2007. Technology verification and up scaling: A multidimentional approach of NARC. Proceedings of the Fifth National Technical Working Group Workshop, April 15, 2007, Kathmandu.

Paudel, MN. 2011. Rice (Oryza sativa L.) cultivation in the highest elevation in the world. Agronomy J. Nepal. 2:31-41.

Paudel, MN; NS Thakur; D Gauchan; and RP Upreti.2006. A retrospective and perspective of outreach research in Nepal Agriculture Dev J 2006, 3:3, 1-18

Regenerative agriculture technologies for the hill farmers of Nepal: An information kit, http://nzdl.sadl.uleth.ca/cgi-bin/library, downloaded on 6 Sep 2009.

Sapkota, C.2013, blog: http://sapkotac.blogspot.com/2013/07/poverty-by-district-innepal.html

Singh, RB. 2009. Regional Report on Agricultural Research for Development in the AsiaPacific Region. Asia-Pacific Association of Agricultural Research Institutions (APAARI) and Asian Development Bank (ADB) In Collaboration with: Global Forum on Agricultural Research (GFAR)

Structural economic transformation in Nepal: A diagnostic study submitted to DFID Nepal. http://www.odi.org/sites/odi.org.uk/files/odi-assets/publications-opinionfiles/9019.pdf Retrieved on 4 Feb 2016.

The Gorkhapatra, daily.2009, October 16, 2009, Kathmandu, Nepal.

The Kathmandu Post, daily, October 15, 2009. In Saner food future by Anil Bhattarai, Kathmandu, Nepal.

UNO (United Nations Organization) World Food Report. 2008. UNO, Geneva.

WFP (World Food Program). 2009. Food shortage in Nepal different newspaper publications from Nepal. 